\title{
Planning and the Gender Equality Duty - why does gender matter?
}

\author{
Gemma Burgess* \\ University of Cambridge
}

\begin{abstract}
Summary
There are many gendered patterns in the use of space, but planning policy tends to ignore the fact that men and women use space differently. This paper argues that this has resulted in built environments that often disadvantage women and do not meet their needs. From 2007, new legislation in the form of the Gender Equality Duty required public authorities involved in planning and regeneration to take gender equality into consideration. The paper outlines the Duty and draws on ongoing research to reflect on some examples where gender is being taken into account in planning policy and practice. However, as the research is also showing that these efforts are few and far between, the paper argues that there is a long way to go for the real potential for change afforded by the Gender Equality Duty to be realised.
\end{abstract}

Keywords: Gender, Equality, Duty, Planning.

\section{Introduction}

Planning policy has tended to ignore the fact that women and men use public space differently and have different concerns about how it meets their needs. In April 2007 the Gender Equality Duty came into force, requiring public authorities to promote gender equality and remove gender discrimination. The Duty implies that a more explicit consideration of gender is needed in both how planning is delivered and in its wider impacts.

Planners and practitioners involved in urban regeneration programmes and spatial planning will need to examine who benefits from their projects - men and/or women and to take appropriate action on the results. It is argued that the integration of gender into spatial policy-making would result in a more sustainable, equal and accessible built environment for all members of society (Greed, 2005).

In the light of UK policy intended to create sustainable, mixed communities through regeneration and the planning system and the new legislative framework to impose consideration of gender, it is an opportune moment to consider how gender is being taken account of in planning policy and practice. Previous research looked at how planning has already been affected by legislation around issues of equality and 
diversity (Booth et al, 2004). This work argued that planning policies and processes can unwittingly be insensitive to some groups and/or individuals, and may well, unintentionally, discriminate against some sections of society (lbid).

Research is currently being conducted at the University of Cambridge, funded by the Higher Education Council for England and the Royal Institution of Chartered Surveyors, to look at examples of local authorities that have made efforts to take gender into account in planning and/or where the Gender Equality Duty has made an impact. The Duty required that public authorities have Gender Equality Schemes in place by April 2007 and that they report on their progress in April 2008. Thus whilst the legislation has only recently been introduced, it is possible to look for early examples where the Duty has engendered changes to planning policy and/or practice.

The research has involved interviews with local authority officers and related planning practitioners to explore what difference the Duty has made to their work, what barriers they face in implementation and in what ways they are already working to explicitly consider gender in planning. The research has also involved discussion with organisations interested in gender and planning and the new Duty, such as those involved in Oxfam's 'Regender' training programme and the Women's Design Service.

\section{Gendered space}

The relationship between gender and space has been long explored (for example, see McDowell, 1983; Massey, 1994). Looking through the lens of gender shows how notions of maleness and femaleness have influenced our built environment, the locations in which we invest meaning, and the ways we live, work and travel (Domosh and Seager, 2001). The place of women in the built environment has been explored (Bowlby, 1984) and the gender relations of the places in which we live have been explored.

The urban has been identified for some time as a key spatial scale through which gender is experienced and constituted (McDowell, 1983). As a conceptual framework, the urban shows how space and place, as materially grounded social constructions, shape the ways gender identities and relations are played out, reinforced or modified (Bondi and Rose, 2003). Urban form and process and locational differences within cities thus actively construct gender as well as other social relations (Ibid). This is an active process, cities and the places in which we live are not just the scenery for the playing out of gender (Garber \& Turner, 1995), but the built environment plays a role in shaping gendered identities, practices and power relations.

Feminist geographers have examined the multiple gendered (re)makings of urban public space (Bondi and Rose, 2003). During the 1990s one of the main foci of urban studies enthusiastically embraced by geographers (Mitchell, 1995), was the development of critical perspectives on material and representational dimensions of public space and their implications for social identities and citizenship (Bondi and Rose, 2003). Geographers have understood public space to be constituted by impositions, negotiations and contestations over which groups comprise the 'public' that has access to these spaces, for what purposes these spaces are used, and what visions of society urban public space embraces, enforces, produces and promotes (Ibid).

Central to understanding the impact of social relations on the city is recognising the specific imprint of gender relations (Little, 1994; McDowell, 1983; Bondi and Christie, 2000). Social relations have a spatial context and are underpinned by relations of power. There is a correlation between power and space - what gets built, where, how 
and for whom (Beall, 1997). Cities are literally concrete manifestations of ideas on how society was, is and how it should be (Ibid). The way the urban environment, our cities, towns, suburbs, villages etc., are designed and built are imbued with particular understandings of how they will be used that are not gender-neutral. This applies to all the spaces in which we live, work and travel, both the urban and the rural, all are planned and designed with underlying, if implicit, assumptions about gendered social relations.

Members of the 'women and planning' movement, comprising urban planners, geographers, architects and urban designers, have long been active in trying to change spatial-policy and urban design (Greed, 1994a; Roberts, 1991 and Greed, 2005). They have argued that the integration of gender into spatial-policy-making would result in a more sustainable, equal and accessible built environment for all members of society (Greed, 2005).

\section{Gender and spatial planning}

This section of the paper addresses more explicitly the gender issues that planning policy and practice ought to address and highlights some of the problems that result from gender-blind planning. It has been recognised that gender has affected urban planning and the design of the spaces where people live and work (Fainstein and Servon, 2005). Although there are many gendered patterns in the use of space, planning policy tends to ignore the fact that men and women use public space differently. It has been argued that urban and suburban spaces support stereotypically male activities and planning methodologies reflect a male-dominated society (Fainstein and Servon, 2005). Gender differences have implications for all aspects of spatial planning and the design of the built environment (Greed and Reeves, 2005), from the interior design of housing (Roberts, 1991) to the planning of entire cities (Darke et al, 2000). It has been argued that it is most commonly women who suffer disadvantage within a built environment that has often been developed with little reference to their needs (Greed, 2005).

There are many examples of the differently gendered uses of space. Women make more complex journeys than men (Blumenberg, 2004), often travelling to childcare, school, work, and shops in journeys that are often referred to as 'trip-chains' (McGuckin and Murakami, 1999; Greed, 2005). More than twice as many women as men are responsible for escorting children to school, seventy-five per cent of bus journeys are undertaken by women and only thirty per cent of women have access to the use of a car during the daytime (Greed, 2007). Poor public transport and lack of caring facilities and shopping outlets near employment locations restrict women's access to the labour market. Women feel less safe than men being out alone after dark (Whitzman, 2007), especially in the inner city, or social housing estates. Poorly considered land-use zoning policy separates residential areas from employment locations, with a greater impact on women's mobility.

\section{What could considering gender in planning achieve?}

It is argued that there would be a number of consequences if gender were really taken into account in planning. Oxfam have been involved in raising awareness of the need to consider gender. They argue that when planning takes into account the different needs of women and men, this would lead to public transport routes that support women's travel patterns, measures to make public space feel safer at night, employment 
opportunities locally, meaning more mixed use development. The result, Oxfam argues, would be that more women would be able to take employment, training, and leisure opportunities, economic development opportunities would be increased and social inclusion programmes would be more effective (Oxfam, 2007).

There are detailed suggestions as to what can be done in terms of making planning policy and implementation more gender sensitive. For example, consultation around plans, policy and regeneration projects should involve both women and men (Brownhill and Darke, 1998; Escott and Whitfield, 2002). Women should be fully involved in the decision-making processes both as officers and as members of the public (Greed, 2005). Statistics and data need to be disaggregated by sex, race, age and disability and if necessary bespoke surveys may need to be commissioned for plan-making (RTPI, 2007). Data need to be collected for both women and men's activities, in respect of travel, work, care duties and leisure requirements (Greed, 2005). The location of jobs and homes must be considered so that women, who take on most of the caring roles, have an equal chance to access job opportunities and men can take on more caring responsibilities (RTPI, 2007). A fully integrated public transport system would be developed, and ancillary facilities (such as creches, baby changing facilities, public toilets with disabled facilities, public seating) would be provided in a manner that was convenient to women's and men's needs, travel patterns and trip chains (Greed, 2005).

Greed argues that there would not be a division between city-wide and local-level policy issues, but they would be included side by side in all strategic documents. This is because the most basic local factors (such as lack of street lights or inaccessible building locations) can undermine high-level urban sustainability strategies. All these policies would reduce the need to travel, create more sustainable cities that were also more accessible for all, whilst creating a higher quality of urban design (Greed, 2005).

Whilst it is clear that a consideration of gender could help make regeneration and planning more successful for the communities involved, gender is a relatively 'new' explicit consideration for planners and local authorities. Planning contributes to a wider policy agenda and the planning profession and public sector managers more generally have, until recently, overlooked the importance of gender. However, this consideration is now a legal requirement through the Gender Equality Duty.

\section{The Gender Equality Duty}

The UK policy agenda has not been completely devoid of a focus on gender. Gender mainstreaming was endorsed as the official policy approach to gender equality in the European Union and its member states in the Amsterdam Treaty of 1997 (Rees, 2005) and broadly means putting a gender equality perspective into mainstream policies. However, gender mainstreaming has not been well understood. It has tended to be approached in a technocratic way and to be non-systemic in compass, and is underdeveloped as a concept (Daly, 2005). It has been hard to discern the mainstreaming of gendered perspectives into general policy-making (Squires and Wickham-Jones, 2004) and gender has not yet been effectively mainstreamed into the work of local planning authorities in the UK (Greed, 2005). The Gender Equality Duty presents an opportunity for gender to be considered in policy making in a way the mainstreaming agenda did not achieve, given the legislative requirements of the Duty.

Achieving a gender duty has been a long struggle for activists. A public sector duty to promote race equality has been in place since 2000 , following the Stephen Lawrence inquiry, and a similar duty in relation to disability was introduced in 2006. The Gender Equality Duty emerged as part of this general shift in legislation. The 
Equality Act (2006) amends the Sex Discrimination Act (1975) by placing a statutory duty on all public authorities when carrying out their functions to have due regard to the need to eliminate unlawful discrimination and harassment (CLG, 2007). Following the models established for race equality and disability equality in public bodies, the Single Equality Act 2006 introduced in Part IV of the Equality Act the Gender Equality Duty. The Duty is the equivalent of a lawful overarching obligation on public authorities which will require them as employers and service providers to promote equality of opportunity between men and women (CLG, 2007).

In November 2006, Ministers laid the Secondary legislation before Parliament which from April 2007 required public authorities (PAs) to draw up and publish a gender equality scheme which should identify gender equality objectives and show the steps that PAs will take to implement them. PAs are also required to address the causes of any gender pay gaps.

Fundamentally, the duty requires more than equal treatment for men and women (Equal Opportunities Commission, 2007). Public bodies must promote and take action to bring about gender equality. This involves looking at gender equality issues for men and women, understanding why inequalities exist and how to overcome them and creating effective service provision for all, so that everyone can access services that meet their needs (Ibid).

Public authorities also have to ensure that they assess the impact of new legislation, policies, employment and service delivery changes. In complying with the specific duties, they must now consult with employees and stakeholders when drawing up gender equality schemes and impact assessments. They have to publish and be accountable in what they do and through their actions demonstrate their commitment to gender equality. This means that local authorities will be required to promote gender equality in the design and delivery of services provided to the public, not just within their own workforce. In addition, individuals will no longer have to bring cases against local authorities in order to get gender inequalities dealt with. The onus will now be on local authorities to eradicate discrimination and to promote gender equality. This means that planners will increasingly be required to show explicitly how they have considered the gendered impacts of regeneration programmes and spatial plans.

The Gender Equality Duty is legally enforceable but individuals cannot themselves take legal action against public bodies to enforce the specific duties. Enforcement of the general duty can only be achieved by judicial review in the High Court. Responsibility for enforcement of the specific duties resides with the Equality and Human Rights Commission (EHRC). The Commission will be assessing public authorities' schemes to see how they meet the Duty and will be following the progress of different public bodies in implementing their schemes.

The Commission has produced general guidance and codes of practice for public authorities, but there is currently no specific guidance for planners on what the Duty means for their work.

\section{What are practitioners doing?}

There are examples of good practice where gender has been taken into account in planning, some of which pre-date the new legislation. At the city or local authority scale, gender considerations can be mainstreamed into spatial planning policy areas, such as housing and employment. Gender can be linked into other high-level overarching policy issues, such as sustainability, economic growth and social inclusion, particularly through regeneration programmes (Greed, 2007). For example, in raising awareness of 
the Duty, Oxfam gives the example of Lewisham. The London Borough of Lewisham uses an Equalities Impact Assessment spreadsheet in which gender implications and other equality issues are assessed for each policy area in the Unitary Development Plan. As a result, Lewisham shifted its policy on employment site provision to provide more local jobs to benefit women and reduce long-distance commuting (Oxfam, 2007).

Further examples have been identified through the ongoing research being undertaken at the University of Cambridge. The research has involved interviews with local authority officers and planning practitioners to explore what difference the Duty has made to their work, what barriers they see in implementation and in what ways they are already working to explicitly consider gender in planning. The examples drawn from the research given here reflect some of the different ways in which gender is being considered in planning policy and practice.

For gender to be considered in planning, it needs writing into policy and the links between gender and planning need to be made explicit in equality schemes. For example, the Greater London Authority (GLA) has been very proactive in taking the equality agendas into account in policy making and this includes gender equality. The GLA's Gender Equality Scheme deals explicitly with regeneration and urban planning. The Scheme recognises the need for involving women in consultation, stating the need to 'ensure the effective engagement of girls and women in London's regeneration and ensure regeneration meets their needs' (GLA, 2007). In regeneration policy the GLA states that, "women need access to employment and training opportunities close to home, access to good local services, access to affordable childcare, access to convenient, affordable and safe public transport and an urban environment welldesigned for personal safety' (GLA, 2007).

Public participation and consultation are widely sought on planning and regeneration issues. However, to address the needs and concerns of both men and women they need to be equally involved. The research found examples where awareness of the Gender Equality Duty led local authority planners to reflect on the consultations they were conducting and to make changes to ensure they were enabling both men and women to participate. For example, in a local authority community alliance in Nottinghamshire, local authority officers noticed that it was harder to engage men in consultations. The majority of people involved were mothers working part-time. They trialled different approaches to achieve a more even gender balance in their work. For instance, they extended their opening hours to include some evenings and weekends. This helped increase the involvement of working women and men. They have also tried to engage with men in different places such as bookmakers and working men's clubs. This helped to make involvement in consultations closer to half men and half women.

Other local authorities have worked with local women's groups to encourage their input into high level urban plans. Local authority officers are involved in plan-making that will shape the development of cities and often work with consultants. The Duty prompted some local authority planners to re-consider how these plans were made and to try and involve local women. For example, in a South Yorkshire local authority officers piloted a 'community safety audit' in a Neighbourhood Development Frameworks (NDF) area. The NDF will provide a strategic framework for investment, planning and development in parts of the city over the next decade. The audit recruited a group of local women to go on a 'walkabout' around the city with designers. The women's views have since been written into the designer's planning brief. The local authority now requires all designers and consultants to include proposals for including consultation with local women in tenders for any new developments. 
The introduction of the Duty has led to a degree of knowledge-sharing and awareness-raising amongst practitioners. The local authority mentioned above has been particularly proactive in engaging with the requirements of the Gender Equality Duty, for example, organising a seminar with key decision makers from within the local authority and the city more broadly to debate and discuss how gender impacts on regeneration and planning in all areas of the city. Staff have participated in Oxfam's ReGender programme and regeneration and other policies have been revised to make them more gender sensitive.

The ReGender training programme was designed to guide practitioners on how to take account of gender in regeneration and planning. Participants described different ways in which they have been trying to do this, in ways which will help them to meet the requirements of the Duty. Some participants have been raising awareness amongst colleagues through seminars and newsletters. One planning officer had been involved in an impact assessment of a regeneration schemes to assess the impact of local initiatives on women and to make recommendations for improvements. One local authority is planning to implement gender budgeting, to look at the gendered costs and benefits of new developments.

There are practical steps that can be taken by planners and regeneration practitioners to begin to implement the Gender Equality Duty and the examples given above reflect the efforts that some practitioners are making. This research is still ongoing but it is clear so far that many local authorities have not yet managed to engage with the real implications of the legislation. Many gender equality schemes are not yet in place and gender impact assessments have in many cases not been completed. Local authorities seem to find it easier to consider gender equality internally in terms of their organisation itself, for example by reviewing policies relating to recruitment and equal pay, than to engage with the gendered impacts of the services they provide and the policies they implement. There are positive signs, such as local authority officers attending training about gender and regeneration/planning and the Duty, and consultations are underway on gender equality schemes. It will take time for the new legislation to have an impact whilst awareness is raised about what it means in practice, and whilst consultations are carried out to draft new policies and schemes.

Interviews with local authority officers during the research suggest that there are a number of barriers to realising the potential of the legislative change. They have found that other strands of the equalities agenda have been prioritised over gender. As one local authority officer said, 'Gender has been last in people's response to the equality agenda. Race has been emphasised more and for longer', (Personal communication, May 2008). A number of participants in the research said that they found it difficult to understand the legislation and what it means in practice. There were very few local authorities that have directed extra resources towards implementing the requirements of the Duty in planning departments. Some interviewees described a lack of interest and even a degree of hostility from colleagues when they returned from training around gender equality in their sector. Perhaps unsurprisingly, most of the local authority officers who have been on training around gender, planning and regeneration are women. In local authorities that have been more proactive and engaged, it is the result of one or two passionate individuals or senior women in management roles in the council who have been driving the efforts, rather than a broader commitment to gender equality. One interviewee said that the legislation now gives their efforts to have gender taken seriously some real 'clout', but said that it 'is a slow, tortuous process'. 


\section{Conclusions}

On a positive note, a number of planning and regeneration practitioners have undertaken training to increase gender awareness in their roles, so there may be more examples of good practice emerging in the near future.

Whilst a number of examples of gender being considered in regeneration and planning have been identified, it is clear that as yet the impact of the Gender Equality Duty on planning has been minimal in this field. The research has found that engaging with gender issues in planning and regeneration is not yet established practice. There are cases where good practice is evident, but they are not the norm. The research also suggests that initiatives to consider gender tend to be driven by one or two individuals with a particular interest in this issue, rather than being widespread through planning or regeneration teams.

There are limits as to how far the Duty goes in relation to monitoring and evaluation of outcomes. Public authorities were required to have Gender Equality Schemes in place by April 2007 and should have reported on the schemes in April 2008, although the EHRC are aware that many have as yet failed to do so. It is not clear how the EHRC will review the schemes or what the results of this review process will be.

There are implications for local authority planners, both professional implications for planning officers in terms of the skills required and in terms of the senior management commitment that will be required to really implement the Duty. Resources will need to be allocated to support implementation. In order to have a broader impact, the importance of considering gender needs to have corporate backing across a local authority or city to prevent actions being undertaken by only a handful of interested individuals. More advice and training is needed to give planners and regeneration practitioners information about how to turn the requirements of the new legislation into practical actions. Implementation of the Gender Equality Duty will need to be linked with the other equality duties and more work still needs to be done to raise awareness of the Duty.

The research suggests that local authority planning officers are mostly addressing women's disadvantage in terms of issues of access, transport and safety, rather than issues of gender income disparities, educational achievements or poverty inequalities. Planning and the built environment is just one aspect of a more complex whole and there has been acknowledgement of the limits to what planning can achieve (Booth et al, 2004). The other parts of the market system and the policy processes that combine to produce inequalities also need to be readjusted to ensure more equal treatment of women or disadvantaged groups more generally. The reliance on legislation to progress gender inequalities is positive, but must also be supported by broader changes in policies and practices to address gendered disadvantage. Planning and the built environment alone cannot redress fundamental inequalities.

However, given the inter-relationships between gender, space and power, the form and function of the built environment can make a difference and should not be overlooked. This legislation could be used to try to bring about quite radical transformations in the nature of urban space and the social relations within it. Rather than simply leading to policy changes that support the status quo, such as recommending the locating of childcare facilities near to women's employment, the Duty could be used to encourage more fundamental shifts in how we live and work and the gendered social relations that underpin these activities. The Duty was welcomed by feminists for its radical potential in transforming the gendered social relations of urban space. Whilst there are examples of engagement with the legislation, its transformative potential is yet to be realised. 
p. 120. Planning and the Gender Equality Duty - why does gender matter?

*Correspondence Address: Gemma Burgess, Cambridge Centre for Housing and Planning Research, Department of Land Economy, University of Cambridge, 19 Silver Street, Cambridge, CB3 9EP. Email: glb36@hermes.cam.ac.uk.

\section{References}

Beall, J. (1997) A City for All: Valuing Difference and Working with Diversity. London: Zed Books.

Blumenberg, E. (2004) En-Gendering Effective Planning: Spatial Mismatch, Low-Income Women, and Transportation Policy. Journal of the American Planning Association, 70.

Bondi, L. and Christie, H. (2000). Working out the urban: Gender relations in the city, in: Bridge, G. and Watson, L. eds., The Blackwell Companion to the City, 292-306. Blackwell.

Bondi, L. and Rose, D. (2003) Constructing gender, constructing the urban: a review of Anglo-American feminist urban geography. Gender, Place and Culture, 10, 3, 229-245.

Booth, C., Darke, J. and Yeandle, S. (1996) Changing Places: Women's Lives in the City. London: Paul Chapman.

Booth, C., Batty, E., Gilroy, R., Dargan, L., Thomas, H., Harris, N. and Imrie, R. (2004) Diversity and Planning: Research Report on Planning Policies and Practice. London: ODPM.

Bowlby, S., ed. (1984) Women and the built environment. Built Environment 10 (special issue).

Brownhill, S. and Darke, J. (1998) Rich mix: Inclusive strategies for urban regeneration. Policy Press in association and the Joseph Rowntree Foundation.

Communities and Local Government (2007) Gender Equality Scheme 2007-2010. London: Communities and Local Government

Daly, M. (2005) Gender mainstreaming in theory and practice. Social Politics: International Studies in Gender, State \& Society, 12, 3, 433-450.

Darke, J., Ledwith, S. and Woods, R. (2000) Women and the City: Visibility and Voice in Urban Space. Oxford: Palgrave.

Domosh, M. and Seager, J. (2001) Putting Women in Place: Feminist Geographers Make Sense of the World. London: Guilford Press.

Escott, K. and Whitfield, D. (2002) Promoting Gender Equality in the Public Sector. Equal Opportunities Commission.

Equal Opportunities Commission (2007) Overview of the gender equality duty: Guidance for public bodies working in England, Wales and Scotland.

Fainstein, S. and Servon, S. J. (2005) Gender and Planning: A Reader. Rutgers University Press.

Garber, J. A. and Turner, R. S. (eds) (1995) Gender in Urban Research. Thousand Oaks, CA, Sage.

Greater London Authority (2007) Gender Equality Scheme 2007-10. London: Greater London Authority.

Greed, C. (1994) Women and Planning: Creating Gendered Realities. London: Routledge.

Greed, C. (2005) An investigation of the effectiveness of gender mainstreaming as a means of integrating the needs of women and men into spatial planning in the United Kingdom. Progress in Planning, 64, 243-321.

Greed, C. (2006) Institutional and Conceptual Barriers to the Adoption of Gender Mainstreaming Within Spatial Planning Departments in England. Planning Theory \& Practice, $7,2,179-197$. 
p. 121. Planning and the Gender Equality Duty - why does gender matter?

Greed, C. and Reeves, D. (2005) Mainstreaming equality into strategic spatial policymaking: are town planners losing sight of gender? Construction Management and Economics, 23, 1059-1070.

Greed, C. (2007) A Place for Everyone? Gender equality and urban planning. A ReGender Briefing Paper. Oxfam.

Hamilton, K., Jenkins, L.., Hodgson, F. and Turner, J. (2005) Promoting gender equality in transport. Equal Opportunities Commission.

Little, J. (1994) Gender, Planning and the Policy Process. Oxford: Pergamon Press.

Massey, D. B. (1994) Space, Place, and Gender. Minneapolis: University of Minnesota Press.

Matrix (1984) Making Space: Women and the Man-made Environment. London: Pluto.

McDowell, L.. (1983) Towards an understanding of the gender division of urban space. Environment and Planning D: Society and Space, 1, 59-72.

McGuckin, N. and Murakami, E. (1999) Examining Trip-Chaining Behaviour: Comparison of Travel by Men and Women. Journal of the Transportation Research Board, 1693.

Mitchell, D. (1995) The end of public space? People's Park, definitions of the public, and democracy. Annals of the Association of American Geographers, 85, 108133.

Rees, T. (2005) Reflections on the uneven development of gender mainstreaming in Europe. International Feminist Journal of Politics, 7, 4, 555-574.

Roberts, M. (1991) Living in a Manmade World: Gender Assumptions in Modern Housing Design. London: Routledge.

Royal Town Planning Institute (2007) GPN7: Gender and Spatial Planning. RTPI.

Stimpson, C., Dixler, E., Nelson, M. and Yatrakis, K. (eds) (1981) Women and the American City. Chicago: University of Chicago Press.

Squires, J. and Wickham-Jones, M. (2004) New Labour, Gender Mainstreaming and the Women and Equality Unit. British Journal of Politics \& International Relations, 6, 1, 81-98.

Whitzman, C. (2007) Stuck at the front door: gender, fear of crime and the challenge of creating safer space. Environment and Planning A Online. 